\title{
Assessment and management of water resources in Northeastern Algeria: case of watersheds Kebir West Safsaf and Guebli rivers, Skikda
}

\author{
Titi Benrabah Samia $\cdot$ Kherici Bousnoubra Houria • \\ Kherici Nacer · Cote Marc
}

Received: 24 April 2012/Accepted: 28 January 2013/Published online: 26 February 2013

(C) The Author(s) 2013. This article is published with open access at Springerlink.com

\begin{abstract}
In Algeria, as in many other parts of the world, population growth, rapid urbanization, and economic development weigh heavily on water resources. In order to better manage these resources, this paper reports a detailed estimate of groundwater and superficial water of Skikda region, for an appropriate management and adequate use of this resource. Located in north east of Algeria, the study area is composed of three watersheds, covering an area of approximately $4,138 \mathrm{~km}^{2}$. The groundwater is abundant in the region, represented mainly by the alluvial deposits water. This accumulated reserve is yearly renewed thanks to the efficient infiltration of rain water. Moreover, the superficial resources are an important part of water heritage of the region catchment, with a permanent flow of various streams that carry a considerable volume, with important hydraulic structures allowing the mobilization of a certain volume. Water needs are increasing in the same direction as the development of industry and agriculture sectors in the area of study.
\end{abstract}

Keywords Skikda - Assessment - Water resources . Reservoir · Watershed management

T. B. Samia $(\bowtie) \cdot$ K. Nacer

Laboratory of Geology, Badji Mokhtar University,

Annaba, Algeria

e-mail: hydroannaba@hotmail.fr

K. B. Houria

Hydraulic Department, Badji Mokhtar University,

23000 Annaba, Algeria

C. Marc

Géography Institute, Provence University (Aix-Marseille I),

Marseille, France

\section{Introduction}

Fresh water is essential to life, the environment, and to support productive activities, is not an infinite resource. It is unequally distributed by nature on the surface of the globe. Currently, 1.1 billion people; (17\%) of the population lack access to safe water while 2.4 billion people (40\%) lack adequate sanitation. The majority of affected people live in Africa and Asia. Furthermore, population growth, rapid urbanization, and economic development weigh heavily on water resources. In developing countries, water supply depends on large seasonal fluctuations (drought and flooding). Water reserves available in the earth's surface are about 1.386 billion $\mathrm{km}^{3}$ (Detay 1997). The seas and oceans consist of salt water represent $97 \%$ of global water stock and the remaining $3 \%$ are inland waters (groundwater, glaciers, rivers, and lakes).

Algeria has five watersheds with a total area of 2,243,229 $\mathrm{Km}^{2}$ comprising 19 catchment area. The renewable surface water resources are estimated at a total of $13.2 \mathrm{~km}^{3} /$ year across the country. Water contained in the renewable groundwater aquifers in north of the country are estimated at nearly $1.7 \mathrm{~km}^{3} /$ year, and these sheets are fed mainly by rainfall where the distribution is irregular in both space and time (NAHR 2010). Among Algerian watersheds, there those of "Constantinois" center coastal (northeastern Algeria) whose underground and surface water mobilized are around 354 million $\mathrm{m}^{3} /$ year, a considerable amount but still insufficient relative to the growing demand for water by all areas (NAHR 2010) drinking industrial and agriculture water needs.

\section{Background}

The "Constantinois" central coastal (Skikda), with an area of approximately $4,138 \mathrm{~km}^{2}$, is part of "Constantinois"

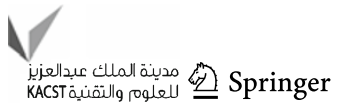


coastal watersheds (located in the North East coast of Algeria). Limited in the north by the Mediterranean Sea, in south by the wilaya of Constantine and Guelma, in east by the wilaya of Annaba and in west by the Jijel, and Mila wilayas (HBA 2010; Fig. 1).

The study area has a population of 1,129,295 inhabitants (census 2008), which is densely located in big cities. Covering an area of 191,119 ha farm, the region is subject to a quite important demand for irrigation water. Industries are abundant, varied and highly concentrated around the town of Skikda (petrochemical pole). From the point of view climate, watersheds Skikda city belong to one of the wettest regions of the North East of Algeria, which is characterized by sub-humid to humid Mediterranean climate. Indeed, rainfall is very important in this region and its distribution is the most important on the well-reliefs where rainfall can reach $1,200 \mathrm{~mm} /$ year (Collo region), and decreases in the valley bottoms, but remains relatively high (800-900 mm/year) compared to other surrounding areas (Marre 1992).

The analysis of the geological environment has revealed that the land consists of metamorphic rocks (gneiss and métapélites), encountered in the North East and North West of study area (Safia mountains and Collo region, Titi Benrabah et al. 2008a, 2009a) and by sedimentary rocks consist mainly of sand, silt, and gravel covering the centre of the region (Fig. 2; Marre 1992; Hydro graphic basin Agency of Constantine and Annaba 2010). The latter formations are the site of two types of aquifers:
Superficial aquifers: formed by gravel and have permeability of $10-3 \mathrm{~m} / \mathrm{s}$ and transmissivity that varies from $3.10-4$ to $10-2 \mathrm{~m}^{2} / \mathrm{s}$ and the storage coefficient is estimated to 5.10-3 (Khammar 1980).

Deep aquifers: formed by the sand, the transmissivity is $2.10-3 \mathrm{~m}^{2} / \mathrm{s}$ and storage coefficient can go up to 3.10-4 (Tesco-Visiterv 1982) from hydrographical point of view, the study area is composed, from east to west by:

- Kebir West river for a length of $43 \mathrm{~km}$ and drains an area of $1,134 \mathrm{~km}^{2}$, with major tributaries: El Aneb and Fendek.

- Safsaf river for a length of $53 \mathrm{~km}$ and drains an area of $1,154 \mathrm{~km}^{2}$, with major tributaries Khemakhem and Haddaratz

- Guebli river for a length of $38 \mathrm{~km}$ and drains an area of $944.6 \mathrm{~km}^{2}$, with major tributaries which are Fessa and Guergour (Titi Benrabah et al. 2009b).

\section{Work methodology}

In this study, various bibliographical documents were consulted and exploited to establish a sufficient synthesis of knowledge. In addition to this, many trips to agencies and involved institutions (ANRH, ABH, MRE, DHW, ANBT, ONID, ADE,...) were done, supplemented by repeated surveys in the field of study. The establishment of surface water balance in the region has required the knowledge of parameters which determine the functioning
Fig. 1 Geographical situation of study ground (Skikda)

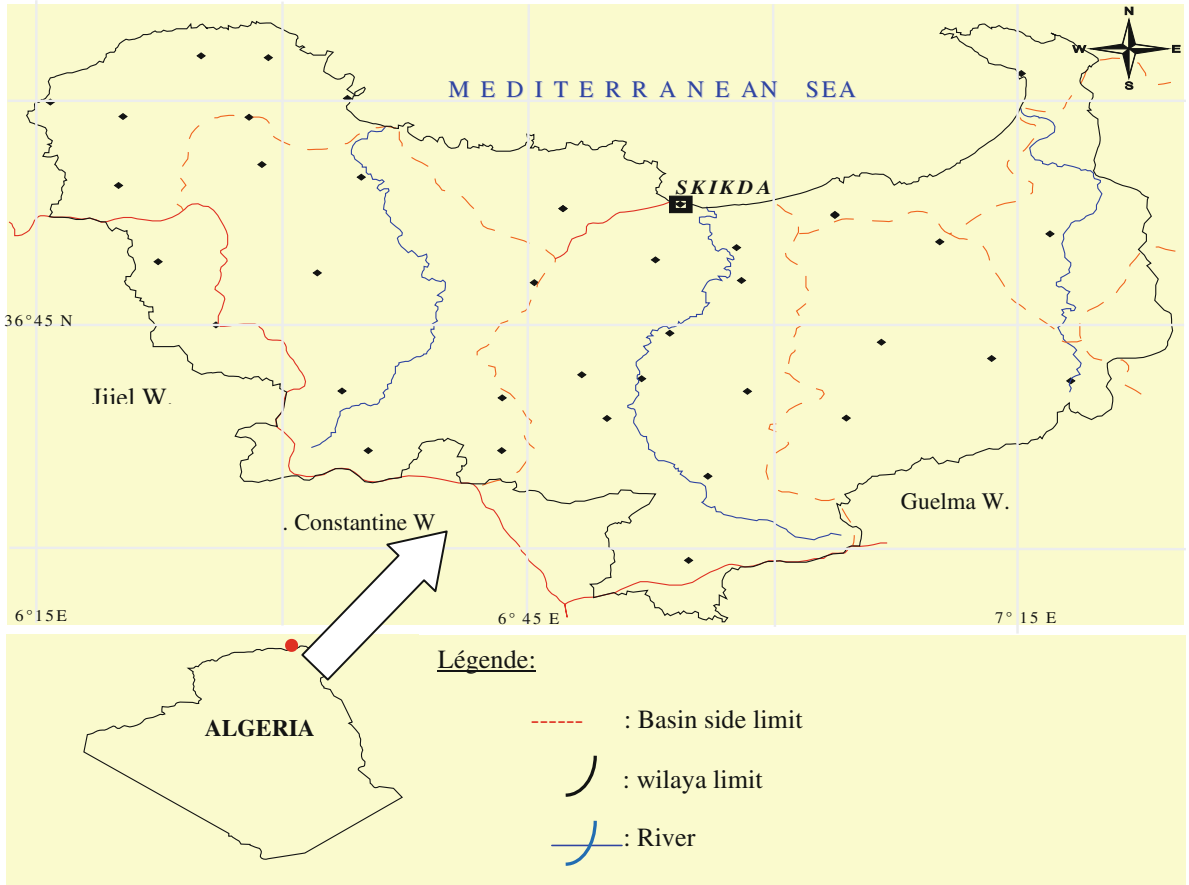


Fig. 2 Hydro-geological section in Skikda reservoir formations (From forages sections and geophysical study)

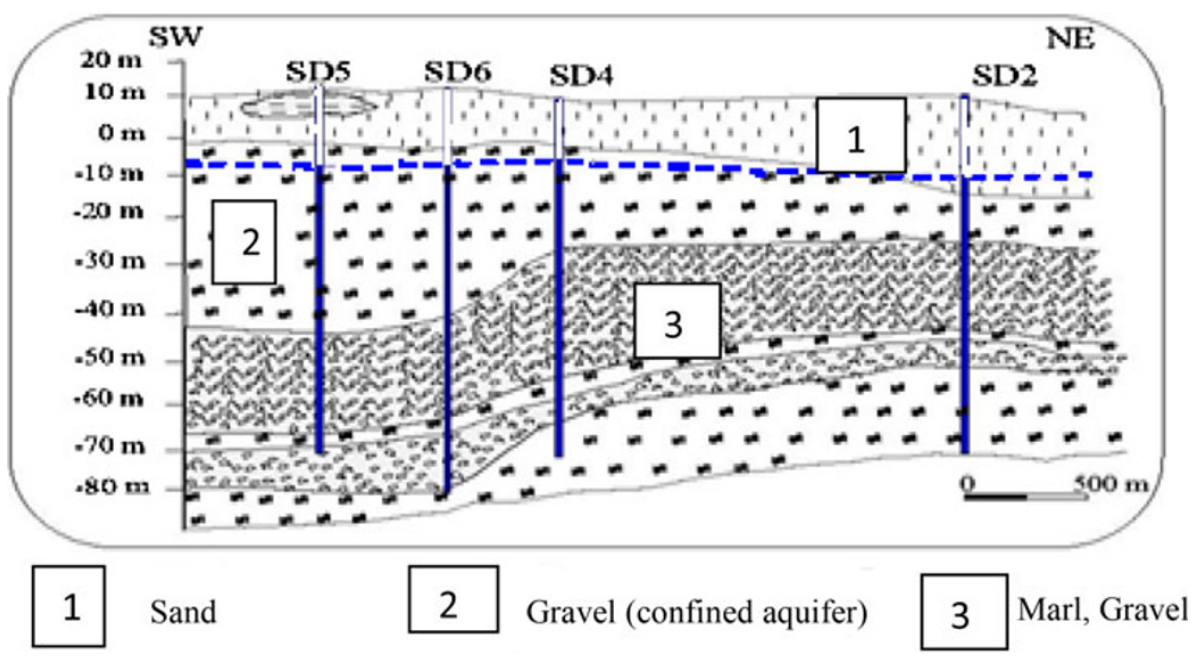

of this system. Average values of climatic data for a period of 10 years were used for this study, which were drawn from the three chosen stations to better represent the whole field, based on criteria deemed necessary for the reliability of this study such as the existence of complete sets for the duration of our study, and their location in the three basins that form the area of study (Villa 1980). The underground water balance is calculated starting from the empirical formula. Actual évapotranspiration is the sum of the processes of evaporation and transpiration of water on a given surface and for a defined period is calculated by the formula of L. Turk (1961). Runoff is determined by the formula Tixeront Berkallof (Titi Benrabah et al. 2008, 2010). For the calculation of potential évapotranspiration,

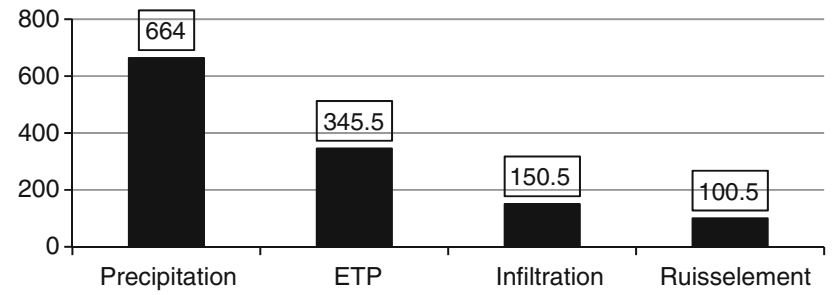

Fig. 3 Rain, infiltration, évapotranspiration, and stream values (2010)

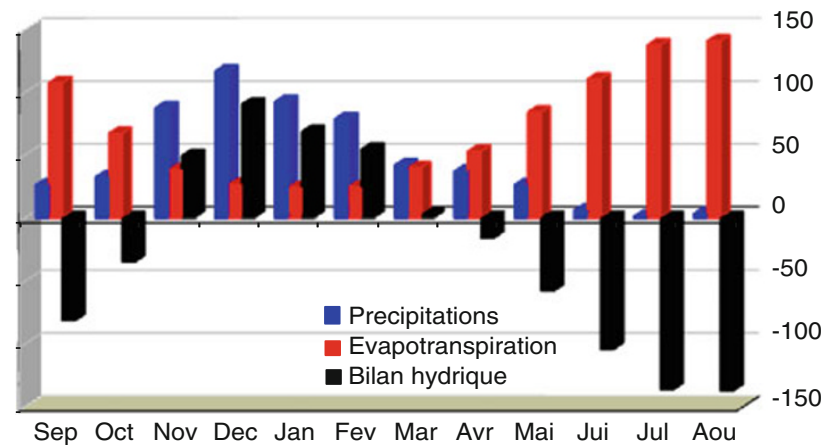

Fig. 4 Hydrous assessments by C. Thorntwaite (2009) we used Thornthwaite formula, which is simply related to the action of climatic factors and do not involve the type of soil or vegetation, (Villa 1980; Titi Benrabah et al. 2006a).

\section{Results and discussion}

In the study area, for an average annual rainfall of $664.19 \mathrm{~mm}$, the average runoff is $100.50 \mathrm{~mm}$, évapotranspiration average is $345.52 \mathrm{~mm}$ (51\% of precipitation is evaporated) and infiltration is $151.50 \mathrm{~mm}$, (Fig. 3; Marre 1992).

The reserve easily usable reaches the maximum starting from December to April where depletion stocks begins (Raoult 1974). The CW Thornthwaite water balance has revealed an agricultural deficit which starts on May until September (Fig. 4; Lallemand Barres and Roux 1999).

\section{Surface water potential}

The surface hydric resources of the different catchments are mainly formed by the permanent flow of the three rivers, which carry an approximate volume of $481 \mathrm{~mm}^{3}$ (Titi Benrabah et al. 2006b, 2009c). These resources insufficiently mobilized by the four dams of the city, the rest flows join the Mediterranean Sea.

In reviewing the (Table 1), we can see that the Kebir West river provides the largest contribution in surface

Table 1 Average yearly supply of rivers in Skikda area (2010)

\begin{tabular}{lccc}
\hline Rivers & $\begin{array}{l}\text { Surface } \\
\left(\mathrm{km}^{2}\right)\end{array}$ & $\begin{array}{l}\text { Contribution } \\
\left(\mathrm{M} \mathrm{m}^{3} / \text { year }\right)\end{array}$ & $\begin{array}{l}\text { Mobilized volume } \\
\text { by dams }\left(\mathrm{M} \mathrm{m}^{3}\right)\end{array}$ \\
\hline Guebli River & 988 & 49 & $117.42,+39.39$ \\
Safsaf River & 1,165 & 150 & 18.11 \\
Kebir West River & 1,169 & 282 & 116.59 \\
Total & 3,326 & 481 & 291.91 \\
\hline & & & \\
& & &
\end{tabular}


Table 2 Capacities and regularized volume of dams (2010)

\begin{tabular}{lrllll}
\hline Dams & $\mathrm{C}\left(\mathrm{M} \mathrm{m}^{3}\right)$ & $\mathrm{R} \mathrm{V}\left(\mathrm{M} \mathrm{m}^{3}\right)$ & $\mathrm{ETP}\left(\mathrm{M} \mathrm{m}^{3}\right)$ & $\mathrm{L}\left(\mathrm{M} \mathrm{m}^{3}\right)$ & $\mathrm{R}(\mathrm{mm})$ \\
\hline Zerdazas & 32 & 18 & 1.59 & 1.46 & 938 \\
Guenitra & 125 & 48 & 5.85 & $\backslash$ & 881 \\
BeniZid & 40 & 20 & 2.92 & $\backslash$ & 1,440 \\
ZitEmba & 120 & 43.4 & 10.56 & 0.36 & 887 \\
Total & 317 & 129.4 & 21 & 1.82 & $\backslash$
\end{tabular}

$C$ Capacities, $R V$ Regularized volume, ETP Évapotranspiration, $L$ Leakage, $R$ Rainfall

water in the region with $58.62 \%$ followed by the Safsaf river with $31.18 \%$ then comes the Guebli river with $10.18 \%$, (Tesco-Visiterv 1982; Brennecke and Couture 2008).

The wilaya of Skikda has four large dams in service with initial total capacity of 317 million $\mathrm{m}^{3}$ for water supply of the various districts, irrigation, and industry. Currently they mobilize only 292 million $\mathrm{m}^{3}$ due to siltation which caused a decrease in their ability to almost $25 \%$ (JORA 2006).

For 2010, Évapotranspiration recorded at these dams is almost 21 million $\mathrm{m}^{3}$. This phenomenon is more intense especially at the Zit Emba dam $\left(10.56 \mathrm{~mm}^{3}\right)$. Leakage at both dams Zerdazas and Zit Emba were evaluated to nearly 2 million $\mathrm{m}^{3}$ in 2009 (Table 2; NAHR 2010).

\section{Seawater desalination}

The only desalination station in the region is that of Ben M'hidi with a production capacity of $10,000 \mathrm{~m}^{3} /$ day. It currently produces an average of $3,000-3,500 \mathrm{~m}^{3} /$ day ensuring the drinking water needs of Ben M'hidi and K'sob regions (1.27 $\mathrm{M} \mathrm{m}^{3} /$ year). Two other stations are planned for a production capacity of, respectively, $100,000 \mathrm{~m}^{3} /$ day (36.5 $\mathrm{M} \mathrm{m}^{3} /$ year), and $50,000 \mathrm{~m}^{3} /$ day $\left(18.25 \mathrm{M} \mathrm{m}^{3} /\right.$ year). With their achievement, the volume of water produced will be almost $58.4 \mathrm{Mm} / \mathrm{year}$, ensuring all water needs of the wilaya (Table 3; HBA 2010; CEAE 2006).

\section{Underground water potential}

The knowledge of an exploitable aquifer and its potential passes by the study of all its parameters (mass transfer,

Table 3 Water volume taken from the underground sheets of Skikda area (2010)

\begin{tabular}{lcll}
\hline Sheets of water & $\begin{array}{l}\text { Number } \\
\text { of wells }\end{array}$ & $\begin{array}{l}\text { Mobilised volume } \\
\left(\mathrm{M} \mathrm{m}^{3} / \text { year }\right)\end{array}$ & $\begin{array}{l}\text { Exploited volume } \\
\left(\mathrm{M} \mathrm{m}^{3} / \text { year }\right)\end{array}$ \\
\hline Safsaf sheets & 53 & 24.12 & 5.50 \\
Kebir West sheets & 56 & 27.39 & 6.75 \\
Guebli sheets & 16 & 5.2 & 1.74 \\
Total & 125 & 56.71 & 13.99 \\
\hline
\end{tabular}

Table 4 Recapitulatory of water amount (surface and underground water) in the study area (2010)

\begin{tabular}{ll}
\hline Water amount $\left(\mathrm{M} \mathrm{m}^{3} /\right.$ year $)$ & \\
\hline Dams & 292 \\
Hills & 1.47 \\
Sea water desalination & 3.65 \\
Wells & 56.71 \\
Total & 353.83 \\
\hline
\end{tabular}

Data from ANRH, ABH, ANB, 2010

transmissivity, capacitive function, permeability,...) (ICPMS 1996). If the volumes are relatively well known, the flow passing through aquifers are much harder to be estimated because the distribution between the effective infiltration of runoff and flows is not known precisely. Thus, changing the resource is therefore very uncertain following in one hand climate change, and how to lead the operation in the other hand. The sub-soil of Skikda region is well provided with groundwater resources, even if all layers do not present important exploitable capacities (sheet sandstones and flysch aquifer in the valley of Safsaf). Alluvial deposits (Quaternary formations), formed along the rivers are the main store of groundwater in the region (Table 4).

The preparation of hydro geologic sections supplemented by various geophysical surveys allowed us to bring into focus extension of the subjacent hydrogeological formations of the region of the study, their lithology and hydrodynamic relations between different layers (Fig. 5; Lallemand Barres and Roux 1999).

The majority of potential underground water is pumped out from a battery of boreholes located in the alluvial plains of (plain Zeramna, Skikda, Tamalous, Collo, and Azzaba). Currently, on a total of 279 wells, only 127 remained in service and mobilize a total of $56.71 \mathrm{M} \mathrm{m}^{3} /$ year 14 million $\mathrm{m}^{3}$ of them are distributed as drinking water supply Table 3 .

\section{Groundwater exploitation rate}

A commonly used indicator for determining the rate of exploitation is the ratio between the flows taken and those which actually pass through the aquifers (Fig. 6). The approximate volume of water infiltrated into the aquifers in the studied area is calculated as a function of infiltration $(\mathrm{mm})$ and surface associated watersheds (Villa 1980). The gram bar represents the estimated exploitation rates for the major aquifers of the study area (Skikda), showing that at present (2009), the overall rate of groundwater exploitation is relatively low because it does not exceed an average of $10 \%$ operating $(9.54 \%$ in the Safsaf valley $10.55 \%$ in the Kebir West Valley and $1.74 \%$ for the Guebli Valley. 
Fig. 5 Map of sheets extension in Skikda area (according to the forages sections and geophysics studies)

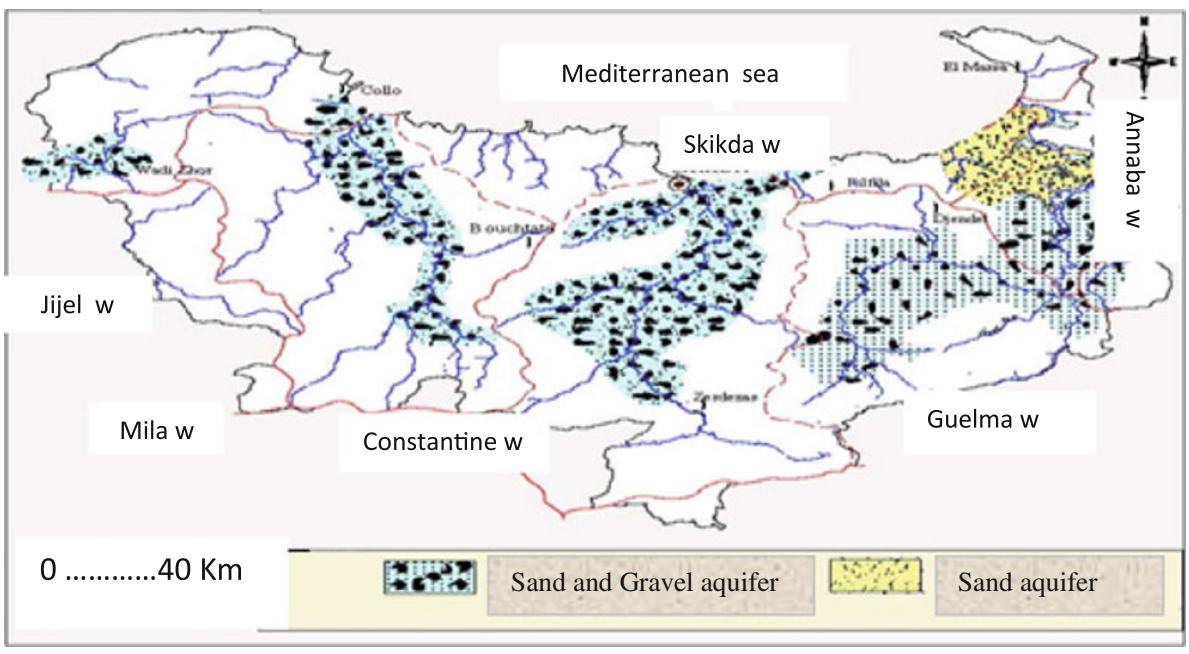

various substances derived primarily from urban and industrial discharges and the leaching of agricultural lands (fertilizers).

The abundance of surface water that are near $96 \%$ compared to groundwater, which is only $4 \%$, although they are best demanded in matter of quality (chemical characteristics in relation to surface water), which requires no treatment after extraction (Table 5).

This abundance is relative to waters above the river, because the total volume of $481 \mathrm{~mm}^{3}, 292 \mathrm{~mm}^{3}$ is mobilized only by the four dams in the region near 1.47 million $\mathrm{m}^{3}$ and mobilized by the 12 dams, adding to the volume taken some of river water directly, the rest flows to the sea (Remenieras 1986; Miquel Revol 2002).

Water needs

Three major activities use nearly $70 \%$ of the total reserve of mobilized surface and groundwater estimated at about 353.83 million $\mathrm{m}^{3}$ in the whole region.

1. The first consumer is agriculture which uses about 112.77 million $\mathrm{m}^{3}$ of the total volume (2009), of which only $25 \%$ is used by plants the rest returns to the water cycle (infiltration, évapotranspiration), (Marre 1992; Lallemand Barres and Roux 1999).

2. Is the second largest consumption of water is drinking water of nearly 64.63 million $\mathrm{m}^{3}$ for year (2008) with about $30-40 \%$ is lost because of leakage.

3. The industry uses about 33.83 million $\mathrm{m}^{3}$ per year as freshwater, and almost 450 million $\mathrm{m}^{3}$ of sea water which present a total of 484 million $\mathrm{m}^{3}$ in 2010 .

For quantitative estimate of drinking water needs, population growth in the region should be taken into account (Mebarki 2005). The number of inhabitants of Skikda city is steadily increasing which means an increase in the Skikda region, this type of water is sometimes threatenec by the high rate of salinity in some wells, and polluted by

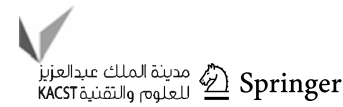



versus increase of DWS $\left(\mathrm{M} \mathrm{m}^{3} /\right.$ year). In the wilaya of Skikda
Fig. 7 Population evolution

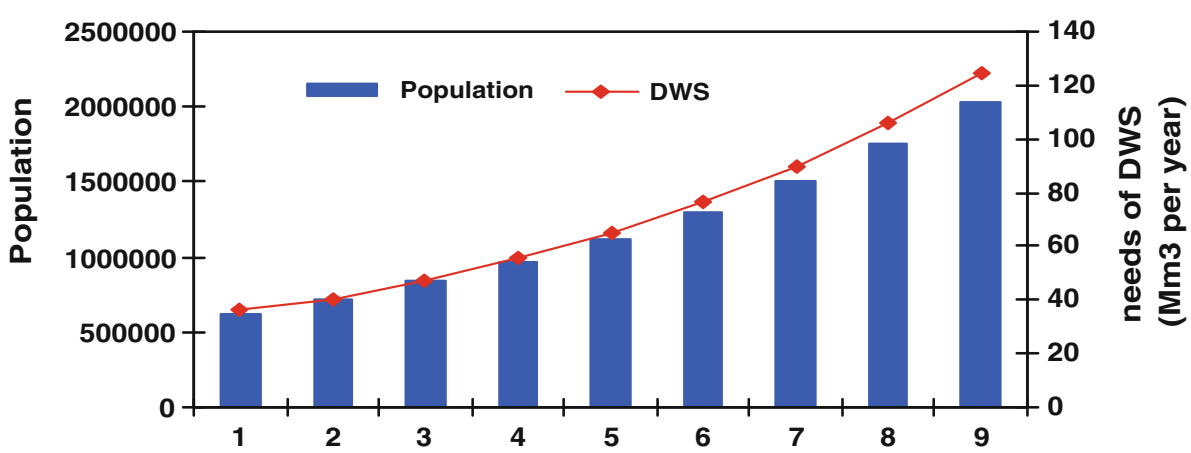

Fig. 8 Evolution of water demands for agriculture and development perspective in the Skikda city (1987-2025)

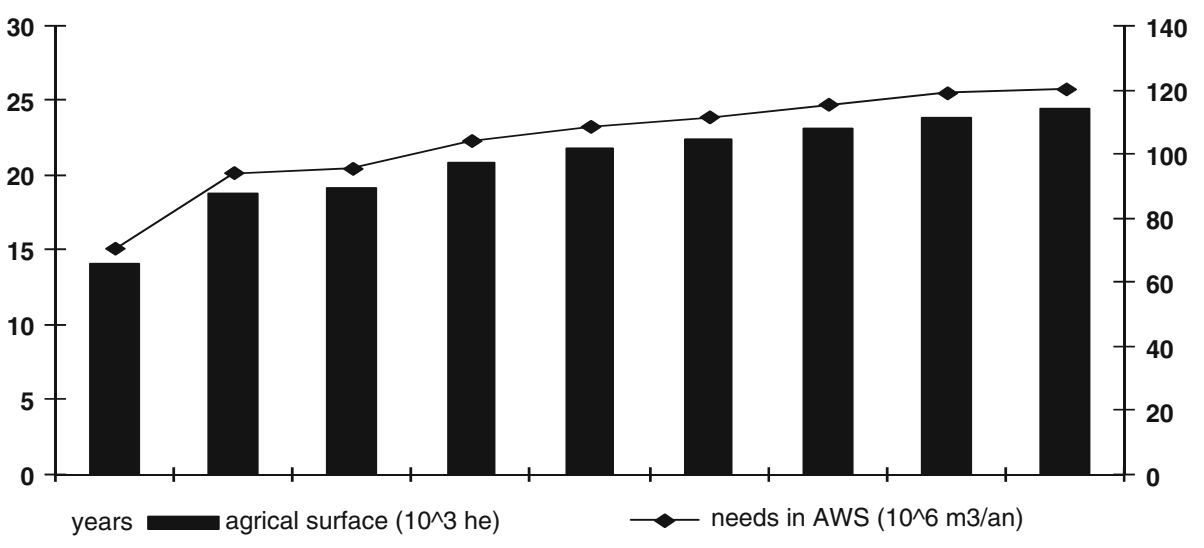

drinking water needs. With an average growth rate of $3.32 \%$ per year, it is possible to illustrate the evolution of the population versus time in the Skikda city in the figure below (Fig. 7)

In December 2010, the volume of mobilized water in Skikda region was about 353.83 million $\mathrm{m}^{3}$ for a population of approximately one million inhabitants. A volume of 64.63 million $\mathrm{m}^{3}$ (supply is distributed to the various Dairas in the wilaya). The estimate for 2,025 is $124.38 \mathrm{M}$ $\mathrm{m}^{3} /$ year. With a population increase to about 2 million inhabitants (almost the double the total mobilized and about nine times the volume currently distributed, USEPA 2005).

The potential of the region in matter of surface and groundwater and soil are important in agriculture. It has allows the development of small and medium hydraulics and irrigation as the major schemes. The total water requirements for agriculture depend on climatic conditions, economic indicators in the region, and the increase in agricultural land (Miquel Revol 2002). It is among the most important cities in agriculture sector with an agricultural area (UAA) of 131,879 ha including 23,276 ha of irrigable land (Fig. 8).

The total irrigated and equipped area in the study region is $9,698.25$ ha for a volume of 46.99 million $\mathrm{m}^{3}$ of water extracted from different sources, was appropriate to staffing $5,000 \mathrm{~m}^{3} /$ ha/year (CNRS 2004) (Table 5). The evolution of water requirements for agriculture is directly linked
Table 6 Demands for water $\left(\mathrm{M} \mathrm{m}^{3} / \mathrm{year}\right)$ in the industrial sector (2010)

\begin{tabular}{ll}
\hline Water needs for industry $\left(\mathrm{M} \mathrm{m}^{3} /\right.$ year $)$ & \\
\hline Dams & 25.37 \\
Wells & 8.46 \\
Sea water & 450 \\
Total & 483.83
\end{tabular}

Data from ANRH, ABH, ANB 2010

to the increase of irrigated farmland. In fact, projecting an increase of 5,000 ha every 5 years, the water requirements for agriculture will increase is as illustrated in the following diagram.

Industries are concentrated around most important cities and their water consumption is extremely variable from one sector to another and despond the type and nature of the activity and the water quality (WHO 2008). This consumption is increasing because of socio-economic impact on the city. Water requirements for the various industrial units of the study area amounted to a total of nearly 33.83 million $\mathrm{m}^{3}$ in 2008 (water dams: 25.37 million $\mathrm{m}^{3}$ of water and drilling: $8.46 \mathrm{~m}^{3}$ ) (Table 6), and more, a considerable amount of sea water for industrial units that use this type of water estimated at 450 million $\mathrm{m}^{3}$ (Heathcote Isobel 1998). 


\section{Conclusion}

The analysis of the geological environment has shown that the field of study is largely formed by sedimentary fields seat in favor of water reserves and metamorphic field. Rainfall is very important, it can reach $1,200 \mathrm{~mm}$, half of which is evaporated, $20-30 \%$ is infiltrated, the rest is runoff (10-20\%). For an annual input of 481 million $\mathrm{m}^{3}$, only 292 million $\mathrm{m}^{3}$ are mobilized by four dams (Zerdazas, Zit Emba Guenitra, and Beni Zid) and the rest goes directly to the sea.

A total of 127 boreholes mobilize a volume of 56.71 million $\mathrm{m}^{3}$ from major aquifers in the region (Safsaf, Kebir West Guebli), however, they remain undermobilized.

The three major activities that use water know an important development which implies a significant increase in water demand; drinking water supply uses about 64.63 million $\mathrm{m}^{3}$ per year where the estimate for the year 2025 is nearly $124.38 \mathrm{M} \mathrm{m}^{3}$, agriculture uses about 47 million $\mathrm{m}^{3}$ of total volume with an estimate for the year 2025 of 112.77 million $\mathrm{m}^{3}$. In the near future, changes in climate could create an unfavorable variance between the growing demand for water in different sectors of the region versus the available water resources. The impact of this factor should lead to a policy of sustainable management of water resources, in which the water should appear as a limited resource, a factor of production and a heritage to be preserved, thus to give the true value of water and its socioeconomic importance.

Open Access This article is distributed under the terms of the Creative Commons Attribution License which permits any use, distribution, and reproduction in any medium, provided the original author(s) and the source are credited.

\section{References}

Brennecke M, Couture M (2008) Indicateurs environnementaux pour les projets d'aménagement du territoire. École polytechnique fédérale de Lausanne. France, p 29

Centre d'expertise en analyse environnementale du Québec (2006) Détermination du phosphore total dissous et du phosphore total en suspension dans les eaux : dosage par méthode colorimétrique automatisée avec du molybdate d'ammonium, MA. 303-P 3.0, Rév. 1, Ministère du Développement durable et de l'Environnement, Québec, Canada

Conseil national de la recherche scientifique (2004) Programme des Nations-Unies pour l'Environnement. GF/6105-92-72, Pub No 3, USA, $p 147$

Detay M (1997) Active management of aquifers. Masson Edition, pp 20-28

Heathcote Isobel W (1998) Integrated watershed management: principles and practice. Wiley, New York, p 400

Hydro graphic basin Agency of Constantine and Annaba. (2010). Unedited Document

International Commissions for the Protection of the Moselle and Saar rivers (CIPM) (1996) A method for assessing water quality of rivers
Journal Officiel de la République Algérienne (2006) Décret exécutif définissant les valeurs limites des rejets d'effluents liquides industriels. p 95

Khammar, C. (1980). Contribution to the hydro geological study of the west Kebir valley in Skikda region, Algeria. PhD Thesis 3rd cycle Grenoble. France, p 176

Lallemand Barres A, Roux JC (1999) Catchment protection perimeters of groundwater for human consumption. Manuals and methods. BRGM edn. p 334

Marre A (1992) The Oriental Tell of Algeria from Collo to Tunisia border, géomorphological study. vol 1, OPU Algeria pp 100-123

Mebarki A (2005) Basin hydrology of eastern Algeria, Water Resources, development and environment. $\mathrm{PhD}$ Thesis State Mentouri University Constantine. Algeria, p 360

Miquel Revol (2002/2003) Water quality and sanitation in France. 215 Report Volume 2

National Agency of hydraulics resources of Constantine and Annaba (2010) Unedited Document

Raoult JF (1974) Geology of the Numidia chain (North of Constantine, Algeria). Memory of the Geological Society of France, p 161

Remenieras G (1986) The hydrology of the engineer. Eyrolles Edition, Paris, p 456

Tesco-Visiterv (1982) Regularization of the Kebir West river (hydrology study). Consulting Engineers, Budapest unedited Document. p 35

Titi Benrabah S (2006) Present state of surface water resources in the wilaya of Skikda assessment-management-perspective. Master thesis, Badji Mokhtar Annaba University, p 160

Titi Benrabah S, Bousnoubra H Bounab. S (2008) Organic matter and eutrophication of wetlands in the Skikda region (case of Kebir west Safsaf and Guebli rivers). International Conf. "Biodiversity and conservation of wetlands" May 8, 1945 Guelma University, 2-4 December 2008

Titi benrabah S Bousnoubra H, Bounab S Bahroun S (2010) Quality degradation of surface water in the region of Skikda (Algerian North East). 1st International Symp on the geology of the Algerian Sahara, Kasdi Merbah University Ouargla, Algeria, 05-07 December 2010

Titi Benrabah S, Bousnoubra H, Bounab S (2006) Evaluation of organic pollution rate in surface water in the wilaya of Skikda. International Symp in Tébessa, 26/27/28 November 2006. "Geoscience for sustainable development"

Titi Benrabah S, Bousnoubra H, Bounab S (2008) Integrated management of water resources and environment at the watershed scale (Skikda). International Symp. "Land and Water 2008" Badji Mokhtar Annaba University 17-19 November 2008

Titi Benrabah S, Bousnoubra H, Bounab S, Bahroun S (2009) Change in concentrations of nitrate and ammonium in the waters of the Skikda region. International Conf. 'the mineral industry and the environment, Simin 09, 3, 4 November 2009, University Badji Mokhtar Annaba

Titi Benrabah S, Bousnoubra H, Bounab S, Bahroun S (2009) Impact of industrial and urban pollution on water quality in the region of Skikda. Second Francophone Conf. "Environment and health" 16-18 May 2009, University Badji Mokhtar Annaba

Titi Benrabah S, Bousnoubra H, Bounab S, Bahroun S (2009) Human impact on the quality of surface waters in the region of Skikda (North East Algeria). Mediterranean Geo engineering Symp. "SMGE 09" STHB University, Algiers, 20 and 21 June 2009

US Environmental Protection Agency, Office of Water (2005) Handbook for developing watershed plans to restore and protect our waters. Washington: United States Environmental Protection Agency, USA, p 400

Villa JM (1980) Alpine chain of eastern Algeria and the AlgerianTunisian border. Doctor of Science thesis 3Tomes Paris, $\mathrm{p} 665$

WHO (2008) Guidelines for drinking-water quality. Recommendations, vol 1, 3rd edn, 3. World Health Organization, Geneva, p 668 